\title{
Species identification and phylogenetic relationships based on partial HSP60 gene sequences within the genus Staphylococcus
}

\author{
Anita Y. C. Kwok, 1,3,5 Shey-Chiang Su, ${ }^{1,2}$ Robert P. Reynolds, ${ }^{1,2,3}$ \\ Sue J. Bay, ${ }^{4,5}$ Yossef Av-Gay, ${ }^{1,3}$ Norman J. Dovichi, ${ }^{4,5}$ \\ and Anthony W. Chow ${ }^{1,2,3,5}$
}
1,2 Departments of Medicine ${ }^{1}$ and Microbiology and Immunology2, University of British Columbia, Vancouver, BC, Canada
3 Vancouver Hospital Health Sciences Centre, 2733 Heather Street, Vancouver, BC, Canada
${ }^{4}$ Department of Chemistry, University of Alberta, Edmonton, $A B$, Canada
5 Division of Infectious Diseases, G. F. Strong Research Laboratories, and the Canadian Bacterial Diseases Network, Vancouver, BC, Canada Author for correspondence: Anthony W. Chow. Tel: + 16048754148 . Fax: + 16048754013.
e-mail: tonychow@interchange.ubc.ca

The phylogenetic relationships among 36 validly described species or subspecies within the genus Staphylococcus were investigated by cloning and sequencing their $60 \mathrm{kDa}$ heat-shock protein (HSP60) genes using a set of universal degenerate HSP60 PCR primers. The cloned partial HSP60 DNA sequences from nine Staphylococcus aureus strains were highly conserved (97-100\% DNA sequence similarity; mean $98 \%$ ), indicating that the HSP60 gene of multiple isolates within the same species have little microheterogeneity. At the subspecies level, DNA sequence similarity among members of S. aureus, Staphylococcus schleiferi, Staphylococcus cohnii and Staphylococcus capitis ranged from 91 to $98 \%$. At the interspecies level, sequence similarity among $\mathbf{2 3}$ distinct species of staphylococci ranged from $\mathbf{7 4}$ to $93 \%$ (mean $82 \%$ ). By comparison, the highest sequence similarity of Bacillus subtilis and Escherichia coli with members within the genus Staphylococcus was only $\mathbf{7 0}$ and $\mathbf{5 9 \%}$, respectively. Importantly, phylogenetic analysis based on the neighbour-joining distance method revealed remarkable concordance between the tree derived from partial HSP60 gene sequences and that based on genomic DNA-DNA hybridization, while 16S rRNA gene sequences correlated less well. The results demonstrate that DNA sequences from the highly conserved and ubiquitous HSP60 gene offer a convenient and accurate tool for species-specific identification and phylogenetic analysis of staphylococci.

Keywords: Staphylococcus, HSP60 gene sequences, 16S rRNA gene sequences, DNA-DNA hybridization, phylogenetic analysis

\section{INTRODUCTION}

According to the current List of Bacterial Names with Standing in Nomenclature (Euzéby, 1997; updated 18 January 1999), the genus Staphylococcus comprises 36 species, nine of which also contain subdivisions with subspecies designation. The majority of these staphylococci are coagulase-negative, with the exception of Staphylococcus aureus, Staphylococcus intermedius,

\footnotetext{
Abbreviation: HSP60, $60 \mathrm{kDa}$ heat-shock protein.
}

The GenBank accession numbers for the sequences reported in this paper are AF033622, AF036322-AF036324, AF053568-AF053587, AF060184AF060191 and U92809.
Staphylococcus delphini, Staphylococcus schleiferi subsp. coagulans and some strains of Staphylococcus hyicus (Kloos \& Bannerman, 1995). Although previously considered to be harmless commensals of the skin and mucous membranes, coagulase-negative staphylococci, along with $S$. aureus, have emerged as the leading cause of bacteremia associated with nosocomial infections (Kloos \& Bannerman, 1995). Thus, there is a pressing need to accurately and rapidly identify and speciate clinically important coagulasenegative staphylococci isolates. Unfortunately, the taxonomic classification and species identification of these micro-organisms remain problematic.

Conventional taxonomic and identification schemes 
Table 1. List of strains and GenBank accession numbers of partial HSP60 and 16S rRNA gene sequences of staphylococci

\begin{tabular}{|c|c|c|c|c|c|c|}
\hline \multirow[t]{2}{*}{ Species } & \multicolumn{2}{|c|}{ HSP60 DNA } & \multicolumn{4}{|c|}{ 16S rRNA } \\
\hline & $\begin{array}{l}\text { ATCC or } \\
\text { isolate no. }\end{array}$ & $\begin{array}{c}\text { GenBank } \\
\text { no. }\end{array}$ & $\begin{array}{l}\text { ATCC or } \\
\text { isolate no.* }\end{array}$ & $\begin{array}{c}\text { GenBank } \\
\text { no. }\end{array}$ & $\begin{array}{l}\text { Size of } 16 \mathrm{~S} \\
\text { rRNA gene }\end{array}$ & $\begin{array}{l}\text { E. coli 16S } \\
\text { rRNA } \\
\text { nucleotide } 33 \\
\text { homologue } \dagger\end{array}$ \\
\hline S. aureus & ATCC $25923 \ddagger$ & AF053568 & - & - & - & - \\
\hline S. aureus & ATCC 27217 & AF060184 & - & - & - & - \\
\hline S. aureus & ATCC 25178 & AF060185 & - & - & - & - \\
\hline S. aureus & ATCC 12598 & AF060186 & - & - & - & - \\
\hline S. aureus & ATCC 10832 & AF060187 & - & - & - & - \\
\hline S. aureus & ATCC 13565 & AF060188 & - & - & - & - \\
\hline S. aureus & ATCC 14458 & AF060189 & - & - & - & - \\
\hline S. aureus & ATCC 19095 & AF060190 & - & - & - & - \\
\hline S. aureus & ATCC 27664 & AF060191 & - & - & - & - \\
\hline S. aureus & Strain 912 & D14711§ & ATCC 29740 & AF015929§ & 1442 & 33 \\
\hline $\begin{array}{l}\text { S. aureus subsp. } \\
\text { anaerobius. }\end{array}$ & ATCC $35844^{\mathrm{T}}+$ & AF036323 & - & - & - & - \\
\hline $\begin{array}{l}\text { S. aureus subsp. } \\
\text { aureus }\end{array}$ & ATCC $12600^{\mathrm{T}}+$ & AF036324 & - & - & - & - \\
\hline S. arlettae & ATCC $43957 \ddagger$ & AF053580 & DSM 20676 & Z26888§ & 771 & 38 \\
\hline S. auricularis & - & - & ATCC $33753^{\mathrm{T}}$ & D83358§ & 1475 & 34 \\
\hline S. capitis subsp. capitis & $s$ ATCC $27840 \ddagger$ & AF036322 & Same & L37599§ & 1469 & 33 \\
\hline $\begin{array}{l}\text { S. capitis subsp. } \\
\text { ureolyticus }\end{array}$ & ATCC $49324 \ddagger$ & AF053587 & - & - & - & - \\
\hline S. caprae & ATCC $35538 \ddagger$ & AF053574 & $\mathrm{CCM} 3573^{\mathrm{T}}$ & Z26890§ & 771 & 38 \\
\hline S. carnosus & - & - & DSM 20501 & Z26891§ & 771 & 38 \\
\hline S. caseolyticus & ATCC $13548^{\mathrm{T}} \ddagger$ & AF053577 & Same & D83359§ & 1478 & 35 \\
\hline S. chromogenes & - & - & ATCC $43764^{\mathrm{T}}$ & D83360§ & 1475 & 35 \\
\hline S. cohnii subsp. cohnii & $i$ ATCC $29974^{\mathrm{T}} \ddagger$ & AF053582 & Same & D83361§ & 1477 & 35 \\
\hline $\begin{array}{l}\text { S. cohnii subsp. } \\
\text { ureolyticus }\end{array}$ & ATCC $49330^{\mathrm{T}}+$ & AF053581 & - & - & - & - \\
\hline S. delphini & ATCC $49171 \ddagger$ & AF053571 & - & - & - & - \\
\hline S. delphini & Strain Heidy & AF019774§ & - & - & - & - \\
\hline S. epidermidis & $9759 \ddagger$ & AF029245 & ATCC $14990^{\mathrm{T}}$ & D83363§ & 1475 & 35 \\
\hline S. epidermidis & 9759 & U13618§ & - & - & - & - \\
\hline S. equorum & - & - & DSM 20674 & Z26895§ & 771 & 38 \\
\hline S. felis & - & - & ATCC $49168^{\mathrm{T}}$ & D83364§ & 1475 & 35 \\
\hline S. gallinarum & ATCC $35539 \ddagger$ & AF053579 & Same & D83366§ & 1477 & 35 \\
\hline S. haemolyticus & ATCC $29970^{\mathrm{T}}+$ & U92809 & Same & D83367§ & 1475 & 35 \\
\hline S. hominis & ATCC $27844^{\mathrm{T}}+$ & AF053572 & Same & L37061§ & 1468 & 33 \\
\hline S. hyicus & ATCC $11249^{\mathrm{T}} \sharp$ & AF019778§ & Same & D83368§ & 1476 & 35 \\
\hline S. intermedius & CFDD & AF019773§ & ATCC $29663^{\mathrm{T}}$ & D83369§ & 1476 & 35 \\
\hline S. kloosii & ATCC $43959 \ddagger$ & AF053575 & DSM $20676^{\mathrm{T}}$ & Z26898§ & 771 & 38 \\
\hline S. lentus & ATCC $29070^{\mathrm{T}} \%$ & AF053586 & Same & D83370§ & 1480 & 35 \\
\hline S. lugdunensis & ATCC $43809^{\mathrm{T}} \ddagger$ & AF053570 & Same & Z26899§ & 771 & 38 \\
\hline S. pulvereri & - & - & ATCC $51698^{\mathrm{T}}$ & АВ009942§ & 1497 & 53 \\
\hline S. saccharolyticus & - & - & ATCC $14953^{\mathrm{T}}$ & L37602§ & 1527 & 42 \\
\hline S. saprophyticus & ATCC $15305^{\mathrm{T}} \ddagger$ & AF053578 & Same & D83371§ & 1477 & 35 \\
\hline $\begin{array}{l}\text { S. schleiferi subsp. } \\
\text { schleiferi }\end{array}$ & ATCC $43808^{\mathrm{T}} \ddagger$ & AF033622 & CD22-1 & D83372§ & 1476 & 33 \\
\hline $\begin{array}{l}\text { S. schleiferi subsp. } \\
\text { coagulans }\end{array}$ & ATCC $49545_{\ddagger}^{+}$ & AF053585 & - & - & - & - \\
\hline S. sciuri & ATCC $29060 \ddagger$ & AF053583 & NCTC 12103 & Z26901§ & 772 & 38 \\
\hline S. simulans & ATCC $27848^{\mathrm{T}} \ddagger$ & AF053584 & Same & D83373§ & 1476 & 35 \\
\hline S. succinus & - & - & AMG-D1 $^{\mathrm{T}}$ & AF004220§ & 1548 & 56 \\
\hline
\end{tabular}


Table 1. (cont.)

\begin{tabular}{|c|c|c|c|c|c|c|}
\hline \multirow[t]{2}{*}{ Species } & \multicolumn{2}{|c|}{ HSP60 DNA } & \multicolumn{4}{|c|}{ 16S rRNA } \\
\hline & $\begin{array}{l}\text { ATCC or } \\
\text { isolate no. }\end{array}$ & $\begin{array}{c}\text { GenBank } \\
\text { no. }\end{array}$ & $\begin{array}{l}\text { ATCC or } \\
\text { isolate no.* }\end{array}$ & $\begin{array}{c}\text { GenBank } \\
\text { no. }\end{array}$ & $\begin{array}{l}\text { Size of } 16 S \\
\text { rRNA gene }\end{array}$ & $\begin{array}{c}\text { E. coli 16S } \\
\text { rRNA } \\
\text { nucleotide } 33 \\
\text { homologue } \dagger\end{array}$ \\
\hline S. vitulus & ATCC $51145^{\mathrm{T}} t$ & AF053576 & - & - & - & - \\
\hline S. warneri & ATCC $27836^{\mathrm{T}} \div$ & AF053569 & Same & L37603§ & 1470 & 33 \\
\hline S. xylosus & ATCC $29971^{\mathrm{T}}+$ & AF053573 & Same & D83374§ & 1477 & 35 \\
\hline B. subtilis & W168 & M81132§ & TB 11 & AF058766§ & 1512 & 53 \\
\hline E. coli & WK-12 & AE000487§ & Ocular isolate & $\mathrm{AF} 076037 \S$ & 1144 & 33 \\
\hline
\end{tabular}

* These isolates were used for 16S rRNA sequence similarity analysis shown in Table 3.

$\dagger$ Position of nucleotide in 16S rRNA gene which aligned with nucleotide 33 in the 16S rRNA homologue of $E$. coli.

Isolates used for HSP60 sequence similarity analysis shown in Table 2.

$\S$ Previously reported GenBank sequence.

have relied heavily on phenotypic characteristics such as colonial morphology and biochemical profiles, including cell wall peptidoglycan (SchumacherPerdreau et al., 1983) and teichoic acid (Endl et al., 1983) composition, cellular fatty acid analysis (Birnbaum et al., 1994; O'Donnell et al., 1985), acid fermentation products (Kloos \& Bannerman, 1995), phage typing (Martin de Nicolas et al., 1995), serotyping (Pillet \& Orta, 1981) and antibiotic susceptibility patterns (Kloos, 1997). These phenotypic characterizations have severe limitations, in part because of variable expression of certain traits, and ambiguity in the interpretation of their end point reactions (Birnbaum et al., 1991).

Among molecular taxonomic methods, DNA-DNA hybridization and 16S rRNA sequences have been the most proficient for phylogenetic analysis of the genus Staphylococcus (Kloos, 1997). DNA-DNA hybridization determines DNA relatedness by the relative binding of single-stranded DNA in reassociation reactions under stringent or non-stringent conditions, and is the current standard for defining the species or subspecies designation of staphylococci (Kloos \& Bannerman, 1995; Wayne et al., 1987). Members of the same species generally demonstiate relative DNA binding values of $70 \%$ or greater under non-stringent conditions $(50 \%$ or greater under stringent conditions), whereas organisms representing different species within the same genus have values less than $70 \%$ (Kloos, 1997). However, DNA-DNA hybridization is not suited for defining phylogenetic relationships of micro-organisms above the genus level because of the high degree of sequence dissimilarity (Stackebrandt et al., 1992). In contrast, 16S rRNA sequence analysis is well adapted for higher order classifications, but may not discriminate effectively among related members within a given genus or species because of the high degree of sequence similarity (Stackebrandt \& Goebel, 1994).
Thus, both approaches have limitations for taxonomic classification and phylogenetic relationship of microorganisms. Recently, the use of DNA sequences from genes encoding highly conserved proteins for performing phylogenetic and taxonomic analysis, such as the gene sequences of the $60 \mathrm{kDa}$ heat-shock protein (HSP60) (Goh et al., 1996) or the B subunit DNA gyrase protein (Yamamoto \& Harayama, 1995), has been evaluated. HSP60 genes, which encode highly conserved housekeeping proteins that assist in proper protein folding (also known as molecular chaperonins), are ubiquitous in both prokaryotes and eukaryotes. Viale et al. (1994) and Gupta (1995) previously observed that evolutionary trees drawn from the protein sequences of these molecules in eubacteria demonstrate remarkable similarity to those derived from 16S rRNA genes. Furthermore, the HSP60 homologues in mycobacteria (HSP65) were found to be useful for species identification and taxonomic classification of the genus Mycobacterium (Steingrube et al., 1995; Pai et al., 1997). We previously reported that PCR-amplified DNA probes prepared from partial HSP60 genes of $S$. aureus, $S$. epidermidis, $S$. haemolyticus, $S$. saprophyticus, $S$. lugdunensis and $S$. schleiferi were species-specific in dot-blot hybridization against a panel of 55 Staphylococcus species (Goh et al., 1996).

In the current study, we report the use of partial HSP60 gene sequences for the phylogenetic analysis of 36 validly described (Euzéby, 1997) staphylococcal strains representing 28 different staphylococcal species and subspecies. Results were compared to phylogenetic relationships based on DNA-DNA hybridization and published $16 \mathrm{~S}$ rRNA gene sequences.

\section{METHODS}

Staphylococcal isolates. A collection of 36 staphylococcal strains, including nine $S$. aureus and 27 other validly 
described Staphylococcus species or subspecies, were used for this study (Table 1). They were obtained either from the American Type Culture Collection (ATCC), from W. Kloos of North Carolina State University, Raleigh, NC, USA, or from our own collection obtained from the Clinical Microbiology Laboratory of the Vancouver Hospital and Health Sciences Centre, Vancouver, British Columbia, Canada. All isolates were grown in brain-heart infusion (BHI) broth, and subcultured overnight on BHI agar plates for examination of purity and colony characteristics. A single colony was picked for DNA extraction, PCR amplification with HSP60 degenerate primers, cloning and sequencing. Genomic DNA was extracted using the InstaGene matrix (Bio-Rad) according to manufacturer's instructions, with the exception that lysostaphin (Sigma) was added $\left(3 \mathrm{U} \mathrm{ml}^{-1}\right.$ final concentration) to facilitate cell lysis.

PCR amplification. The PCR mixture consisted of $15 \mu \mathrm{l}(\sim 50$ ng) of InstaGene DNA extract, $50 \mathrm{mM} \mathrm{KCl}, 10 \mathrm{mM}$ Tris (pH 8.3), $1.5 \mathrm{mM} \mathrm{MgCl}_{2}$ (GIBCO), $200 \mu \mathrm{M}$ of each dNTP (Pharmacia Biotech), 2.5 U Taq DNA polymerase (GIBCO), and $0.5 \mu \mathrm{M}$ each of the HSP60 degenerate primers, designated $\mathrm{H} 279$ and $\mathrm{H} 280$, as previously described (Goh et al., 1996). These primers, with the nucleotide sequence of 5'-GAATTCGAIIIIGCIGGIGA(TC)GGIACIACIAC-3' and $5^{\prime}$-CGCGGGATCC(TC)(TG)I(TC)(TG)ITCICC(AG)AAICCIGGIGC(TC)TT-3', respectively, amplify an anticipated 600 bp HSP60 DNA. The H279 primer had an $E c o$ RI restriction enzyme digest site while $\mathrm{H} 280$ had a Bam HI digest site (both underscored in the above sequences). The PCR thermal cycling conditions were $3 \mathrm{~min}$ at $95^{\circ} \mathrm{C}$ for 1 cycle, followed by 30 cycles of $37^{\circ} \mathrm{C}$ for $30 \mathrm{~s}$, $72^{\circ} \mathrm{C}$ for $1 \mathrm{~min}$ and $94^{\circ} \mathrm{C}$ for $30 \mathrm{~s}$. The last cycle was at $72{ }^{\circ} \mathrm{C}$ for $10 \mathrm{~min}$. After PCR amplification, a sample of each reaction mixture was analysed by electrophoresis on a $2 \%$ TAE (Tris-acetate-EDTA) agarose gel at $100 \mathrm{~V}$ for $1 \mathrm{~h}$, and DNA was visualized with ethidium bromide under UV light.

Purification of $600 \mathrm{bp}$ HSP60 PCR products, cloning and transformation. The amplified $600 \mathrm{bp}$ PCR products were purified using the QIAquick PCR purification kit (Qiagen). In instances where multiple bands were visualized on the gel, the $600 \mathrm{bp}$ band was cut out and DNA was purified using the QIAquick gel extraction kit. Cloning was performed using the TA Cloning vector pCR2.1 (Invitrogen) as described in the manufacturer's protocol. During the early phase of this study, cloning of some PCR amplified DNA was performed using the plasmid vector pUC19. Kanamycin $\left(50 \mu \mathrm{g} \mathrm{ml}^{-1}\right)$ was used to select for transformants. The presence of a correct insert was verified by PCR amplification using two primers (designated $\mathrm{A} 1$ and $\mathrm{B} 2$ ), which flank the multiple cloning site of the vector and amplify a $900 \mathrm{bp}$ product containing the 600 bp HSP60 DNA. The sequences of these primers were : 5'-GCTTCCGGCTCGTATGTTGTGTG-3' and 5'-AAAGGGGGATGTGCTGCAAGGCG-3', respectively. The PCR thermal cycling conditions for screening were: $96^{\circ} \mathrm{C}$ for $30 \mathrm{~s}$ for 1 cycle, followed by 25 cycles of $94{ }^{\circ} \mathrm{C}$ for $10 \mathrm{~s}, 55^{\circ} \mathrm{C}$ for $30 \mathrm{~s}$ and $72{ }^{\circ} \mathrm{C}$ for $1 \mathrm{~min}$, with the final cycle at $72^{\circ} \mathrm{C}$ for $2 \mathrm{~min}$.

DNA sequencing. Transformed Escherichia coli, containing plasmids with the correct PCR insert, was cultured overnight in $\mathrm{BHI}$ broth containing $100 \mu \mathrm{g}$ ampicillin $\mathrm{ml}^{-1}$. Plasmids from $3 \mathrm{ml}$ overnight broth were purified using the Wizard Miniprep (Promega) according to the manufacturer's instructions. DNA sequencing was performed by the fluorescence-based dideoxy chain-termination method using the universal M13( -20$)$ forward and M13 reverse sequencing primers in an automated DNA sequencer (Applied Biosystems model 373A). Emission data from the fluorescence-tagged reaction mixtures were analysed with the proprietary Macintosh-based software SeqEd (version 1.2.0).

Data analysis. Sequence analysis was performed with the entire $600 \mathrm{bp}$ cloned fragment omitting the primer sequences used to amplify the HSP60 genes (sizes of different clones varied between 552 and $555 \mathrm{bp}$ ). Edited sequences were used for similarity searches of the NCBI BLAST databases (Altschul et al., 1997). Multiple sequence alignments were performed using the CLUSTAL w program, version 1.7 (Thompson et al., 1994). The published HSP60 gene sequences of the Gram-positive bacterium Bacillus subtilis (GenBank accession no. M81132), and the Gram-negative bacterium $E$. coli (AE000487) were included for comparison. Aligned DNA sequences were also translated into protein sequences using the Genetic Data Environment (GDE) program, version 2.3 (Smith, 1997). Phylogenetic analysis was performed using the PHYLIP program package, version 3.57 (Felsenstein, 1995). The unrooted phylogenetic tree was constructed by both the maximum-parsimony method (Fitch, 1971) and the neighbour-joining method using the Jukes-Cantor correction for multiple substitutions according to the one-parameter model (Jukes \& Cantor, 1969). Bootstrapping was performed using 500 iterations. Phylogenetic trees were also generated based on the translated partial HSP60 protein sequences. For comparison, a similar phylogenetic tree was generated using the first 800 nucleotides from the 5 '-end of previously published $16 \mathrm{~S}$ rRNA gene sequences of 29 Staphylococcus species currently available in the GenBank databases (isolates, accession numbers and length of available gene sequences are shown in Table 1).

\section{RESULTS}

\section{Cloned 600 bp partial HSP60 gene sequences of staphylococci}

A library of 36 cloned $600 \mathrm{bp}$ HSP60 PCR products representing 28 validly described Staphylococcus species and subspecies was generated. These PCR products were cloned and sequenced, and their GenBank accession numbers are listed in Table 1. Errors attributed to sequencing when compared to an internal standard of 650 bases were less than $0.2 \%$ and therefore negligible. To further evaluate the reproducibility of DNA extraction, PCR amplification, cloning and sequencing procedures, the partial HSP60 genes of $S$. cohnii subsp. cohnii and $S$. cohnii subsp. ureolyticus were each cloned and sequenced in two separate and independent experiments. There was $100 \%$ agreement between the two independent studies in the consensus sequences derived from both strands for both strains.

\section{Similarity searches of staphylococcal HSP60 DNA sequences}

Searches were performed in the NCBI BLAST databases for DNA sequence similarity with our 36 PCRgenerated staphylococcal partial HSP60 gene sequences. The highest similarity scores (and lowest 


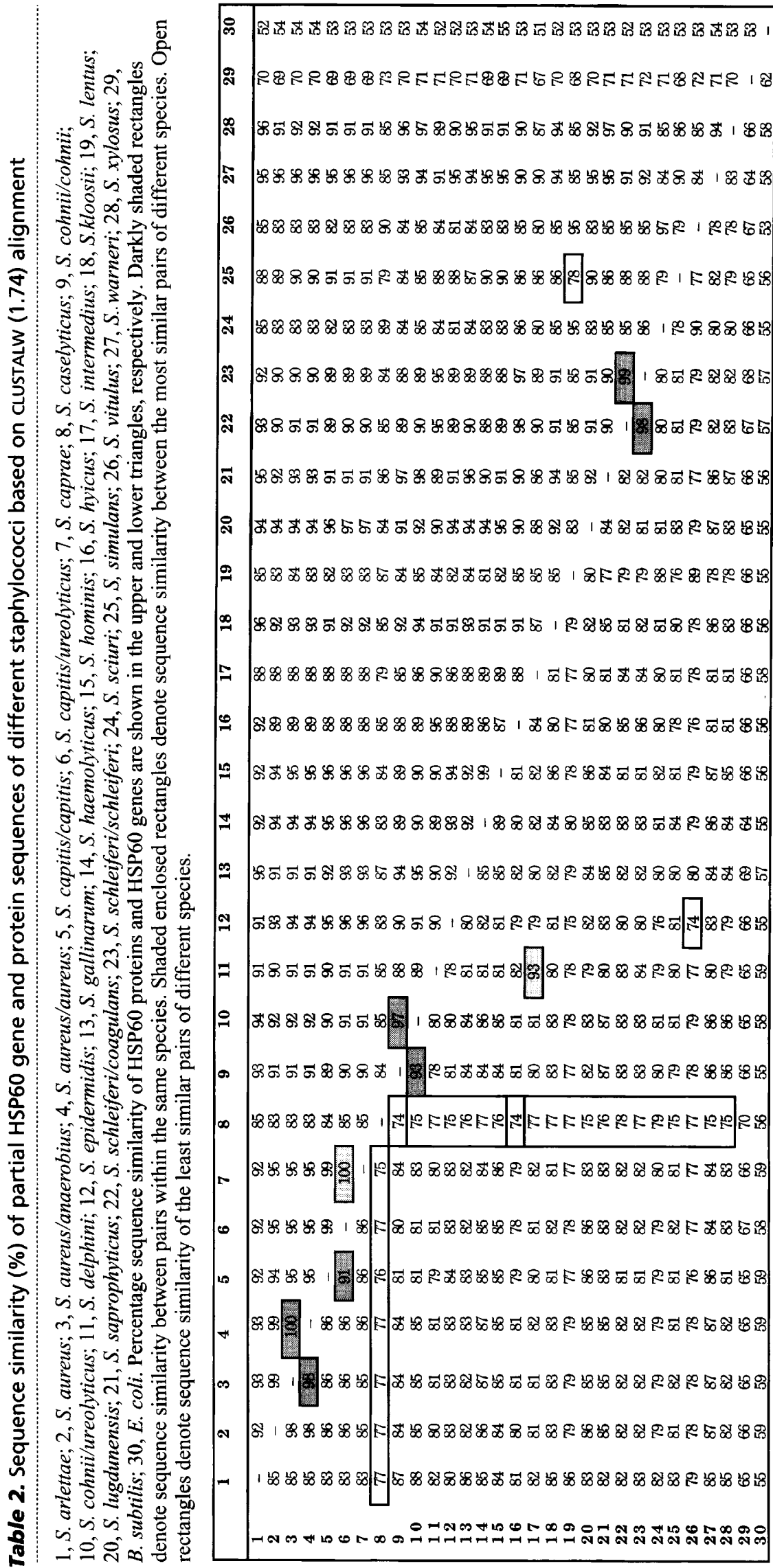


Table 3. Sequence similarity (\%) of 16S rRNA gene sequences of different Staphylococci based on CLUSTAL W (1.74) alignment

Species: 1, S. arlettae; 2, S. aureus; 3, S. auricularis; 4, S. capitis; 5, S. caprae; 6, S. carnosus; 7, S. caseolyticus; 8, S. chromogenes; 9, S. cohnii; 10, S. epidermidis; 11, S. equorum; 12, S. felis; 13, S. gallinarum; 14, S. haemolyticus; 15, S. hominis; 16, S. hyicus; 17, S. intermedius; 18, S. kloosii; 19, S. lentus; 20, S. lugdunensis; 21, S. pulvereri; 22, S. saccharolyticus; 23, S. saprophyticus; 24, S. schleiferi; 25, S. sciuri; 26, S. simulans; 27, S. succinus; 28, S. warneri; 29, S. xylosus; 30, B. subtilis; 31, E. coli.

\begin{tabular}{|c|c|c|c|c|c|c|c|c|c|c|c|c|c|c|c|c|c|c|c|c|c|c|c|c|c|c|c|c|c|c|}
\hline & 1 & 2 & 3 & 4 & 5 & 6 & 7 & 8 & 9 & 10 & 11 & 12 & 13 & 14 & 15 & 16 & 17 & 18 & 19 & 20 & 21 & 22 & 23 & 24 & 25 & 26 & 27 & 28 & 29 & 30 \\
\hline 1 & - & & & & & & & & & & & & & & & & & & & & & & & & & & & & & \\
\hline 2 & 93 & - & & & & & & & & & & & & & & & & & & & & & & & & & & & & \\
\hline 3 & 96 & 96 & - & & & & & & & & & & & & & & & & & & & & & & & & & & & \\
\hline 4 & 99 & 97 & 97 & - & & & & & & & & & & & & & & & & & & & & & & & & & & \\
\hline 5 & 96 & 90 & 96 & 95 & - & & & & & & & & & & & & & & & & & & & & & & & & & \\
\hline 6 & 96 & 90 & 96 & 95 & 96 & - & & & & & & & & & & & & & & & & & & & & & & & & \\
\hline 7 & 92 & 94 & 93 & 94 & 91 & 92 & - & & & & & & & & & & & & & & & & & & & & & & & \\
\hline 8 & 96 & 96 & 97 & 97 & 96 & 96 & 94 & - & & & & & & & & & & & & & & & & & & & & & & \\
\hline 9 & 97 & 97 & 97 & 97 & 98 & 97 & 94 & 97 & - & & & & & & & & & & & & & & & & & & & & & \\
\hline 10 & 99 & 98 & 97 & 99 & 95 & 96 & 94 & 97 & 97 & - & & & & & & & & & & & & & & & & & & & & \\
\hline 11 & 96 & 91 & 96 & 95 & 98 & 96 & 92 & 96 & 98 & 96 & - & & & & & & & & & & & & & & & & & & & \\
\hline 12 & 96 & 96 & 97 & 97 & 95 & 96 & 94 & 98 & 96 & 97 & 95 & - & & & & & & & & & & & & & & & & & & \\
\hline 13 & 95 & 97 & 97 & 97 & 98 & 96 & 94 & 97 & 98 & 97 & 97 & 97 & - & & & & & & & & & & & & & & & & & \\
\hline 14 & 97 & 98 & 97 & 98 & 97 & 96 & 94 & 97 & 98 & 98 & 96 & 97 & 98 & - & & & & & & & & & & & & & & & & \\
\hline 15 & 97 & 97 & 97 & 98 & 96 & 95 & 94 & 97 & 98 & 98 & 96 & 97 & 97 & 99 & & & & & & & & & & & & & & & & \\
\hline 16 & 97 & 96 & 97 & 97 & 96 & 96 & 94 & 98 & 97 & 97 & 96 & 98 & 97 & 97 & 97 & - & & & & & & & & & & & & & & \\
\hline 17 & 96 & 96 & 97 & 97 & 96 & 96 & 94 & 98 & 97 & 97 & 96 & 98 & 97 & 97 & 97 & 99 & - & & & & & & & & & & & & & \\
\hline 18 & 96 & 90 & 96 & 95 & 97 & 97 & 92 & 96 & 97 & 95 & 97 & 95 & 97 & 96 & 96 & 96 & 96 & - & & & & & & & & & & & & \\
\hline 19 & 95 & 96 & 95 & 96 & 94 & 94 & 95 & 96 & 96 & 97 & 94 & 96 & 96 & 96 & 96 & 96 & 96 & 94 & - & & & & & & & & & & 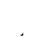 & \\
\hline 20 & 97 & 91 & 97 & 96 & 97 & 96 & 92 & 96 & 97 & 97 & 97 & 96 & 96 & 98 & 97 & 96 & 96 & 97 & 95 & - & & & & & & & & & 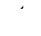 & \\
\hline 21 & 95 & 96 & 95 & 96 & 95 & 94 & 94 & 96 & 96 & 96 & 94 & 96 & 96 & 96 & 96 & 96 & 96 & 94 & 99 & 95 & - & & & & & & & & & \\
\hline 22 & 99 & 98 & 96 & 99 & 95 & 96 & 93 & 97 & 97 & 99 & 95 & 96 & 96 & 97 & 97 & 97 & 96 & 95 & 96 & 97 & 95 & - & & & & & & & & \\
\hline 23 & 95 & 97 & 96 & 97 & 97 & 94 & 93 & 96 & 98 & 97 & 97 & 96 & 98 & 98 & 97 & 96 & 96 & 96 & 96 & 96 & 94 & 94 & - & & & & & & & \\
\hline 24 & 96 & 96 & 97 & 97 & 96 & 96 & 94 & 98 & 97 & 97 & 96 & 98 & 97 & 97 & 97 & 98 & 99 & 95 & 96 & 96 & 96 & 97 & 96 & - & & & & & & \\
\hline 25 & 96 & 90 & 94 & 95 & 95 & 95 & 93 & 95 & 95 & 95 & 95 & 95 & 95 & 95 & 95 & 96 & 95 & 94 & 98 & 96 & 98 & 95 & 95 & 95 & - & & & & & \\
\hline 26 & 96 & 96 & 96 & 97 & 95 & 96 & 94 & 96 & 97 & 97 & 95 & 96 & 96 & 97 & 97 & 96 & 96 & 95 & 96 & 95 & 95 & 96 & 96 & 96 & 94 & & & & & \\
\hline 27 & 96 & 97 & 97 & 97 & 98 & 96 & 94 & 97 & 98 & 97 & 98 & 96 & 99 & 98 & 97 & 97 & 97 & 98 & 96 & 97 & 96 & 95 & 98 & 97 & 95 & 96 & - & & & \\
\hline 28 & 97 & 97 & 97 & 98 & 95 & 95 & 94 & 97 & 98 & 98 & 96 & 97 & 98 & 98 & 98 & 97 & 97 & 96 & 96 & 97 & 96 & 97 & 97 & 97 & 95 & 96 & 98 & - & & \\
\hline 29 & 96 & 97 & 96 & 97 & 98 & 95 & 94 & 97 & 98 & 97 & 98 & 96 & 99 & 98 & 98 & 97 & 97 & 97 & 96 & 97 & 96 & 96 & 99 & 97 & 95 & 96 & 99 & 98 & - & \\
\hline 30 & 90 & 91 & 91 & 91 & 90 & 90 & 91 & 91 & 91 & 91 & 90 & 91 & 90 & 91 & 91 & 91 & 91 & 90 & 91 & 90 & 91 & 89 & 91 & 91 & 91 & 9] & 91 & 90 & 91 & - \\
\hline 31 & 74 & 73 & 76 & 76 & 73 & 73 & 76 & 76 & 76 & 76 & 73 & 76 & 76 & 76 & 76 & 76 & 76 & 74 & 76 & 74 & 76 & 76 & 76 & 76 & 74 & 76 & 76 & 77 & 76 & 77 \\
\hline
\end{tabular}

probability of a random match) were obtained with the sequences from $S$. aureus, $S$. epidermidis, $S$. intermedius, $S$. hyicus and $S$. delphini, each matching with the HSP60 DNA sequences of the corresponding Staphylococcus species currently available in the databases (Table 1).

\section{Sequence similarity in partial HSP60 genes and proteins among different Staphylococcus species and subspecies}

Alignments of HSP60 DNA and protein sequences from nine different $S$. aureus isolates and 28 different Staphylococcus species or subspecies were obtained using the CLUSTAL w program. DNA sequence similarity among the nine different $S$. aureus isolates ranged from 97 to $100 \%$ (mean similarity $98 \%$ among 36 pairwise comparisons among these nine isolates). Protein sequence similarity among these nine isolates ranged from 98 to $100 \%$ (mean similarity $99 \%$ ) (data not shown).

Sequence similarity in partial HSP60 DNA and proteins among 28 different Staphylococcus species or subspecies as well $E$. coli and $B$. subtilis is shown in
Table 2. At the subspecies level, the HSP60 DNA sequence similarity among paired members of the same species ranged from 91 to $98 \%$, with the most similar pairs between $S$. aureus subsp. aureus and $S$. aureus subsp. anaerobius and between $S$. schleiferi subsp. schleiferi and $S$. schleiferi subsp. coagulans ( $98 \%$ sequence similarity each), and the least similar pair between $S$. capitis subsp. capitis and $S$. capitis subsp. ureolyticus $(91 \%)$. At the interspecies level, HSP60 DNA sequence similarity among the entire set of 23 different Staphylococcus species ranged from 74 to $93 \%$ (mean $82 \%$ ) among 253 pairwise comparisons, with the most similar pair between $S$. intermedius and $S$. delphini $(93 \%)$, and the least similar pairs between $S$. caseolyticus and $S$. hyicus, $S$. caseolyticus and $S$. cohnii subsp. cohnii, and S. epidermidis and S. vitulus ( $74 \%$ for each pair, respectively). Among the different Staphylococcus species studied, S. caseolyticus was the least similar in HSP60 DNA sequences, with similarity values ranging from 74 to $79 \%$ (mean $76 \%$ ) when aligned with other members of the genus Staphylococcus. By comparison, the maximum similarity in the HSP60 DNA sequences between the Gram-positive $B$. subtilis and different members within the genus 
Table 4. CLUSTAL $W$ alignment of partial HSP60 DNA (upper) and translated protein (lower) sequences showing hot spot region

Symbols: '*', identical or conserved residues in all sequences in the alignment; ' $\because$ ', conserved substitutions; ', , semiconserved substitutions. Fonts in upper section: regular, C; bold, A; italic regular, T. Fonts in lower section: regular, small hydrophobic residues (AVFPMILW); bold, acidic residues (DE); italic regular, basic residues (RHK); italic bold, hydroxyl, amine or basic residues (STYCNGQ).

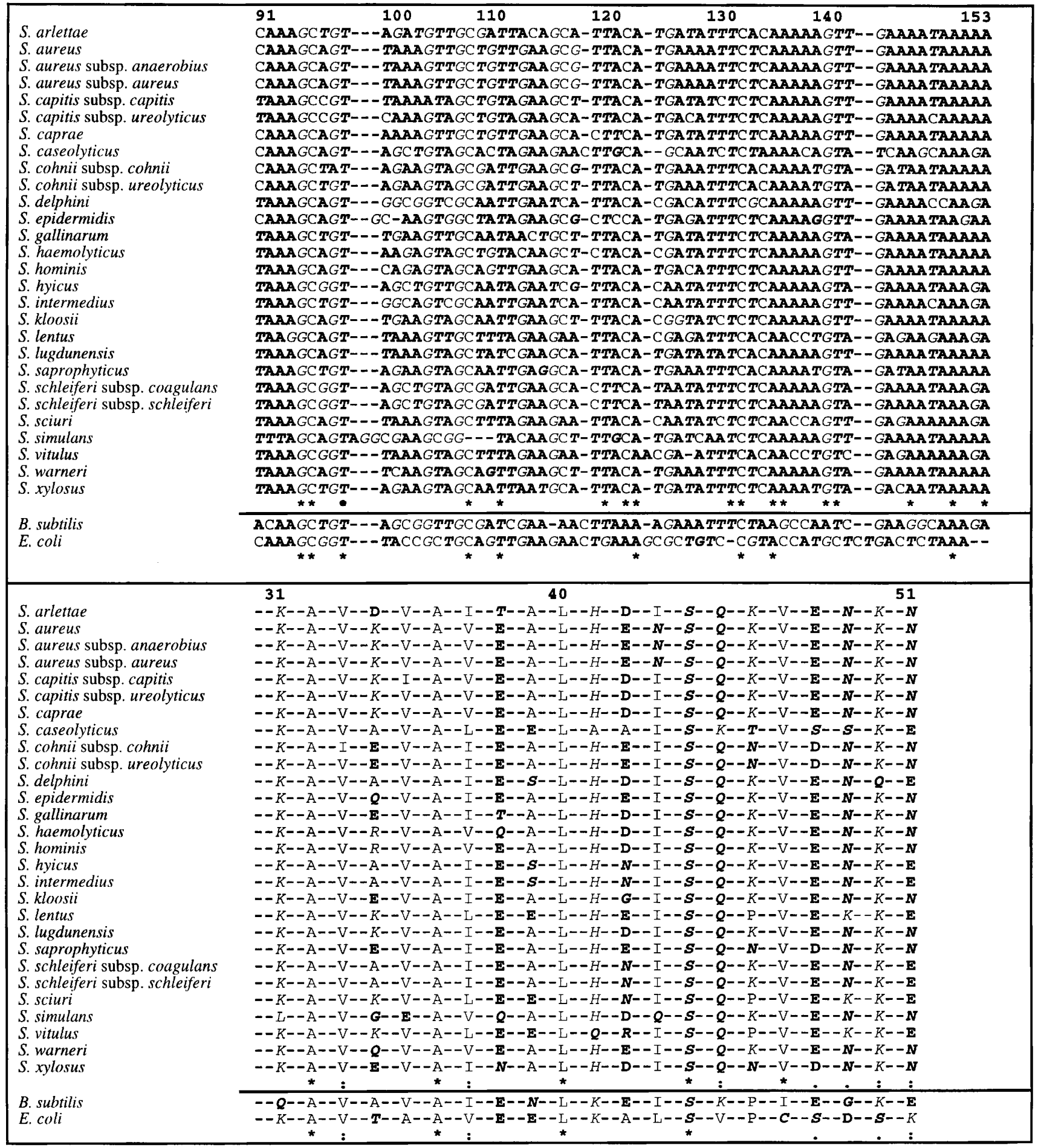

Staphylococcus was $70 \%$ (mean $66 \%$ ), and that between the Gram-negative $E$. coli and different members within the genus Staphylococcus was $59 \%$ (mean 57\%). This degree of HSP60 DNA relatedness is comparable to the HSP60 DNA sequence similarity of $62 \%$ between $B$. subtilis and E. coli. 
(a) HSP60 DNA sequence

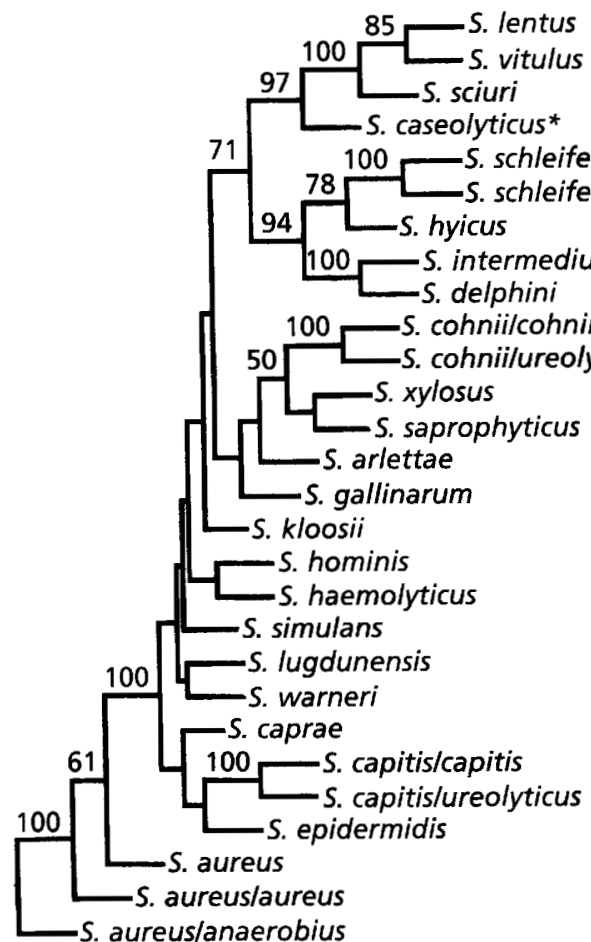

(c) DNA-DNA hybridization

DNA relatedness at optimal conditions (\%)
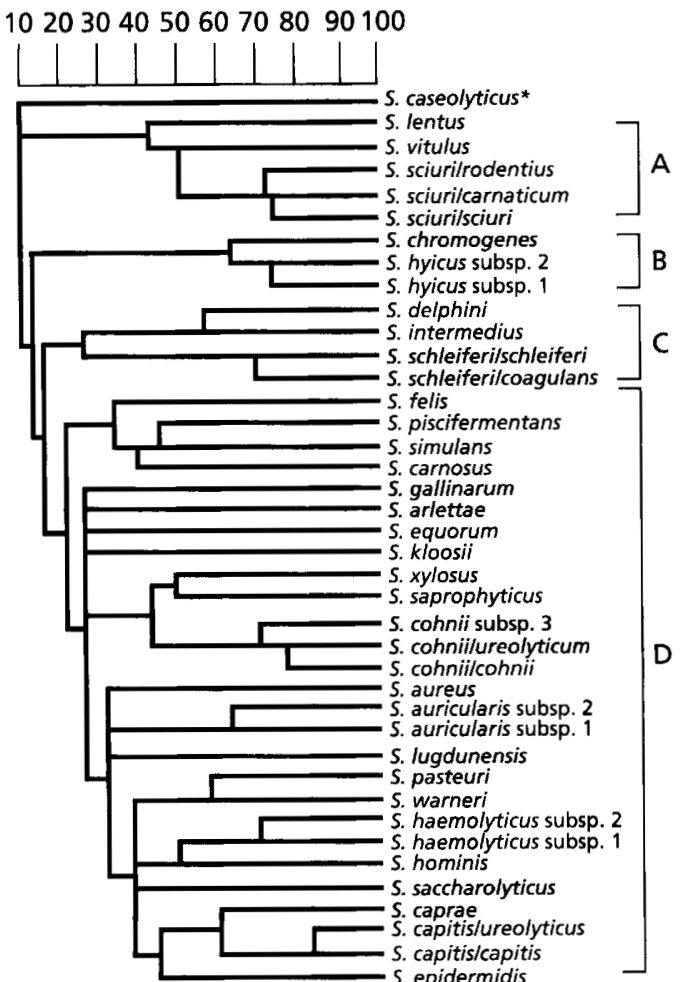

(b) HSP60 protein sequence

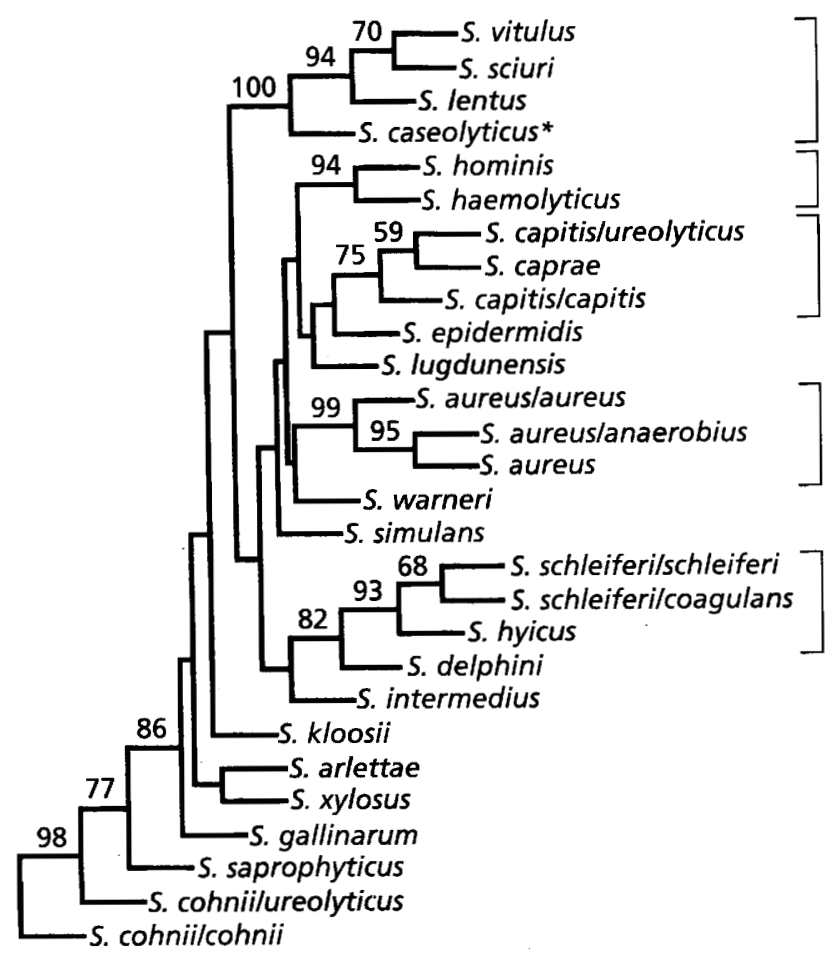

(d) 165 rRNA gene sequence

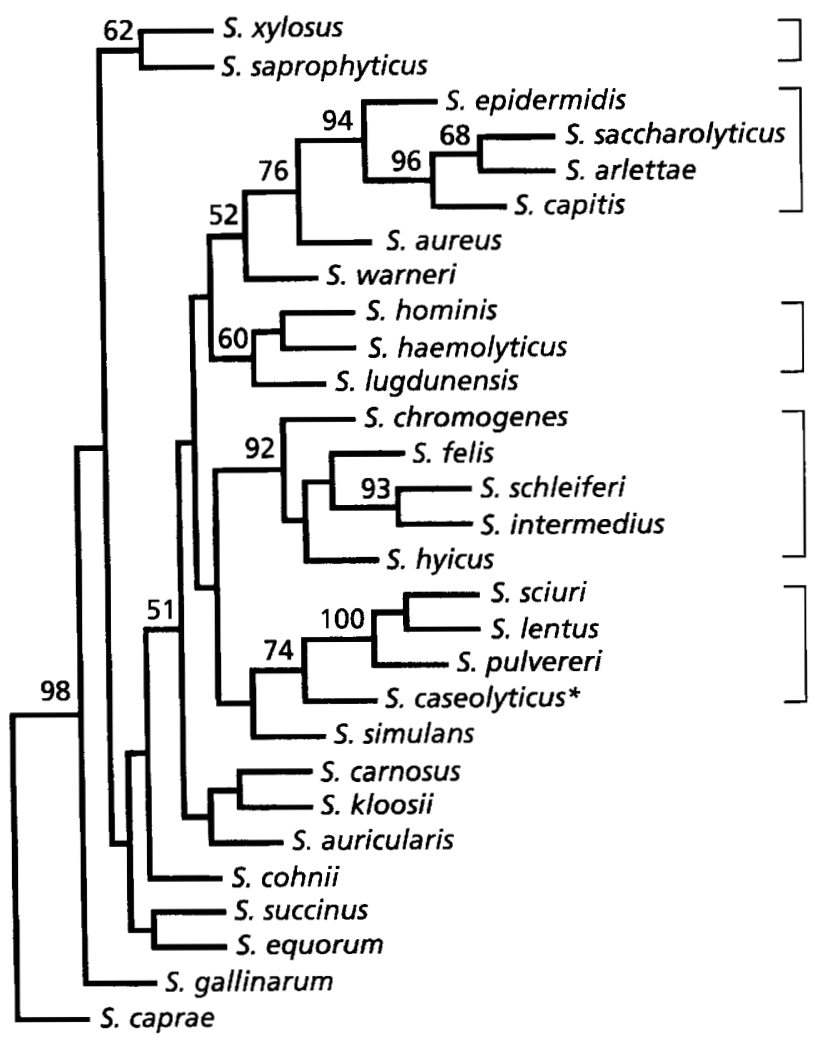

Fig. 1. For legend see facing page. 
HSP60 protein sequence similarity among these 28 different Staphylococcus species and subspecies was also examined (Table 2). As expected from the degeneracy of the genetic code, the amino acid sequence similarity between any given pair was always higher than that of the corresponding DNA sequences between the same pair. The amino acid sequence similarity values ranged from $78 \%$ (between $S$. lentus and $S$. intermedius) to $100 \%$ (between $S$. aureus subsp. aureus and $S$. aureus subsp. anaerobius, and between $S$. caprae and $S$. capitis subsp. ureolyticus, respectively) among 378 pairwise comparisons. The HSP60 proteins of $S$. vitulus, $S$. lentus and $S$. sciuri appear to be highly related to each other as demonstrated by their high similarity scores $(97 \%$ between $S$. vitulus and $S$. sciuri, $95 \%$ between $S$. vitulus and $S$. lentus, and $95 \%$ between $S$. lentus and $S$. sciuri). This contrasts with the mean of $90 \%$ similarity for the entire group of 28 Staphylococcus species and subspecies. Conversely, these three species along with $S$. caseolyticus appeared to share the least similarity in HSP60 protein sequences with other members of the genus Staphylococcus since their mean similarity scores when aligned with other members of Staphylococcus species $(84.6,84 \cdot 7,84 \cdot 8$ and $84.8 \%$ for $S$. lentus, $S$. caseolyticus, $S$. vitulus and $S$. sciuri, respectively) were lower than the mean similarity score for the entire group $(90 \%)$. The percentage similarity in HSP60 protein sequences of $B$. subtilis and $E$. coli with different members within the genus Staphylococcus were comparable to that of their corresponding HSP60 DNA sequences (mean 70 and $53 \%$, respectively).

\section{Comparison of sequence similarity in 16S rRNA genes with HSP60 DNA among different Staphylococcus species}

Similarity values for $16 \mathrm{~S}$ rRNA gene sequences among 29 different Staphylococcus species ranged from 92 to $99 \%$ (mean 96\%) (Table 3). These values were consistently higher than those for HSP60 gene sequences (range 74-93\%, mean $82 \%$ ) (Table 2). This indicates that 16S rRNA sequences are less discriminatory among the different Staphylococcus species as compared to HSP60 DNA sequences. The data in Table 3 also reveal that 16S rRNA gene sequences of these Staphylococcus species were more related to $B$. subtilis (mean similarity $91 \%$; range $90-91 \%$ ) than to E. coli (mean similarity $75 \%$; range $73-77 \%$ ).

\section{Analysis of HSP60 DNA and protein sequences by multiple sequence alignment}

The DNA multiple sequence alignments of 28 Staphylococcus species and subspecies demonstrated the presence of both conserved and variable regions distributed throughout the partial HSP60 genes (data not shown). However, a region spanning from nucleotide positions $90-153$ was identified which appeared more variable than other regions in the DNA sequences of these genes (Table 4). This appeared to be a 'hot spot' region encoding highly variable amino acid residues corresponding to amino acid residues 30-51. In addition, the partial HSP60 proteins of four Staphylococcus species (S. caseolyticus, S. sciuri. $S$. lentus and $S$. vitulus) shared a similar pattern of amino acid substitutions in five positions [residues 39 (A/S $\rightarrow$ E), $69(\mathrm{Y} \rightarrow \mathrm{F}), 89(\mathrm{~N} / \mathrm{S} \rightarrow \mathrm{K}), 151(\mathrm{~A} / \mathrm{S} \rightarrow \mathrm{T})$ and 175 $(\mathrm{M} \rightarrow \mathrm{L})$ ], which differed from all the other staphylococci.

\section{Phylogenetic analysis}

Phylogenetic analysis of the partial HSP60 gene sequences was performed using both the neighbourjoining and maximum-parsimony methods in the PHYLIP software package, version 3.57c. After 500 bootstrapping replications, the consensus trees derived from the two methods were virtually identical and only the consensus tree by the neighbour-joining method is shown (Fig. 1a). This is contrasted to the consensus tree derived by the neighbour-joining method from HSP60 protein sequences (Fig. 1b). Based on HSP60 DNA sequences, the 28 staphylococcal species and subspecies can be grouped into four major divisions, A, B, C and D (Fig. 1a). S. lentus, $S$. vitulus and $S$. sciuri are highly related to each other within Division A, and together with $S$. caseolyticus, they are readily discriminated from the other staphylococci species. Similarly, S. intermedius and S. delphini are highly related to each other, and with $S$. schleiferi and $S$. hyicus within Division B. S. aureus appears to stand out from all other staphylococci in Division D. The remaining staphylococcal species are loosely grouped into Division C.

The consensus tree based on HSP60 protein sequences yielded essentially similar results, although the divisions were not as clear-cut (Fig. 1b). Thus, $S$. vitulus, S. sciuri, S. lentus and $S$. caseolyticus were

Fig. 1. Phylogenetic relationships among different Staphylococcus species revealed by (a) consensus tree (unrooted) derived by the neighbour-joining method based on partial HSP60 gene sequences after 500 bootstrapping iterations (bootstrap values above $50 \%$ are shown at branch points); (b) consensus tree (unrooted) derived by the neighbourjoining method based on partial HSP60 protein sequences after 500 bootstrapping iterations; (c) genomic DNA relationships of Staphylococcus species and subspecies based on DNA-DNA hybridization [adapted with permission from Kloos et al. (1997)]; and (d) consensus tree (unrooted) derived by the neighbour-joining method based on 16S rRNA gene sequences from GenBank databases after 500 bootstrapping iterations. ${ }^{*}$ S. caseolyticus has recently been reclassified as Macrococcus caseolyticus (Kloos et al., 1998). 
again in a unique cluster similar to Division A in Fig. 1(a). S. hominis and S. haemolyticus were highly related. $S$. aureus and the two subspecies were again in a single cluster with high bootstrap values $(99 \%)$, while $S$. schleiferi, $S$. hyicus and $S$. delphini were again grouped together, although the bootstrap values in the protein consensus tree $(82 \%)$ were not as high that in the DNA consensus tree $(94 \%)$.

The consensus tree based on HSP60 partial gene sequences was remarkably similar to that based on DNA-DNA hybridization reported by Kloos (1997) (Fig. 1c). Thus, S. lentus, $S$. vitulus and $S$. sciuri again formed a unique cluster (similar to Division A in the HSP60 DNA tree). $S$. delphini, $S$. intermedius and $S$. schleiferi were again grouped together (similar to Division B in the HSP60 DNA tree), while $S$. hyicus was in a separate cluster with $S$. chromogenes (the latter was not examined by HSP60 DNA sequencing). The remaining staphylococcal species again formed a large and loosely related grouping (similar to Division $\mathrm{C}$ in the HSP60 DNA tree). Within this large grouping, similar clusters were seen as in the consensus HSP60 DNA tree (e.g. S. xylosus, $S$. saprophyticus and $S$. cohnii; $S$. haemolyticus and $S$. hominis; $S$. caprae, $S$. capitis and $S$. epidermidis). The highly related species of $S$. felis, $S$. piscifermentans and $S$. carnosus were unfortunately not studied by HSP60 DNA sequencing.

In contrast to HSP60 gene sequences, the consensus tree based on published 16S rRNA gene sequences of 29 Staphylococcus species correlated less well with the DNA-DNA hybridization tree (Fig. 1d). Although similarities in clustering patterns were seen, the bootstrap values were generally not high. Similarly to DNA-DNA hybridization and to the consensus HSP60 DNA tree, $S$. epidermidis and $S$. capitis were grouped together, as were $S$. xylosus and $S$. saprophyticus; $S$. hominis and $S$. haemolyticus; $S$. schleiferi and $S$. intermedius; and $S$. sciuri and $S$. lentus. However, a number of discordances were observed. These include the phylogenetic position of $S$. aureus, $S$. felis, S. carnosus and S. simulans, among others.

\section{DISCUSSION}

The accuracy of conventional methods for species identification and taxonomic classification of staphylococci based on phenotypic characteristics is limited (reported to range from 50 to $\sim 70 \%$ ) (Birnbaum $e t$ al., 1991; Ieven et al., 1995; Kloos \& Bannerman, 1995). Rosypal et al. (1966) were among the first to use $\mathrm{G}+\mathrm{C}$ ratios and DNA base composition as a molecular tool for the classification of staphylococci. Since then, DNA-DNA reassociation and 16S rRNA sequence analysis have emerged as two powerful and more accurate molecular tools for the taxonomic classification and phylogenetic analysis of microorganisms (Stackebrandt \& Goebel, 1994; Olsen et al., 1994), including staphylococci (Kloos 1997; Gribaldo et al., 1997; Zakrzewska-Czerwinska et al., 1995). However, although useful for higher hierarchical classifications above the genus level, sequence analysis of 16S rRNA may not provide sufficient resolving power as DNA-DNA reassociation in discriminating between highly related micro-organisms of different species within the same genus (Fox et al., 1992). For example, designation of a species within a given genus would generally include strains with approximately $70 \%$ or greater DNA-DNA relatedness and $5{ }^{\circ} \mathrm{C}$ or less $\Delta T_{\mathrm{m}}$ (Wayne et al., 1987). This degree of DNADNA relatedness generally corresponds to $97.5 \%$ or greater 16S rRNA sequence similarity (Stackebrandt \& Goebel, 1994). Thus, it is clear that the resolving power of DNA-DNA hybridization is substantially higher than that of $16 \mathrm{~S}$ rRNA sequence analysis for highly related organisms. For this reason, DNA-DNA hybridization has remained the reference standard for species designation within the genus Staphylococcus (Kloos, 1997). The value of 16S rRNA sequence analysis lies in the finding that two organisms having less than $97.5 \% 16 \mathrm{~S}$ rRNA sequence similarity would not be expected to have more than $60-70 \%$ DNA similarity, and are therefore unlikely to be related at the genus level. This obviates the need for more laborious DNA reassociation studies if their $16 \mathrm{~S}$ rRNA sequence similarity is low. Indeed, it would be valuable to identify an alternative target to $16 \mathrm{~S}$ rRNA genes that offers similar discriminatory power at the species level that DNA-DNA hybridization provides currently.

Our results of the phylogenetic analysis of staphylococci indicate that the highly conserved HSP60 gene may be such an alternative. Firstly, HSP60 genes are ubiquitous in both prokaryotes and eukaryotes, and encode highly conserved housekeeping proteins that are essential for the survival of these cells. With rare exceptions [Mycobacterium tuberculosis, Mycobacterium leprae, Streptomyces albus, Sinorhizobium (Rhizobium) meliloti] (Gupta, 1995), only single copies of the gene are present in each genome. These characteristics may render them less subject to random mutations or intraspecies variation. Viale et al. (1994) and Gupta (1995) independently observed that evolutionary trees drawn from the protein sequences of these molecules in eubacteria demonstrate remarkable similarity to those derived from $16 \mathrm{~S}$ rRNA genes, and in some instances, provide additional insights not available from $16 \mathrm{~S}$ rRNA sequence analysis. We previously reported that PCR-amplified DNA probes prepared from partial HSP60 genes of $S$. aureus, $S$. epidermidis, $S$. haemolyticus, $S$. saprophyticus, $S$. lugdunensis and $S$. schleiferi were species-specific in dot-blot hybridization against a panel of 55 Staphylococcus species (Goh et al., 1996). A more recent study using reverse checkerboard hybridization has extended these observations to the identification of a further 25 Staphylococcus species (Goh et al., 1997). No falsepositive result was observed with 24 negative-control isolates of Gram-positive and Gram-negative bacteria. A false-negative result was observed only with $S$. hyicus. In this instance, the PCR-amplified HSP60 
DNA from four bovine $S$. hyicus isolates failed to hybridize with the $S$. hyicus type strain, a porcine isolate. HSP60 DNA sequence data revealed that the bovine $S$. hyicus isolates differed from the type strain at $14 \%$ of 552 bases (i.e. only $86 \%$ similarity), suggesting that these bovine isolates could be a subspecies of $S$. hyicus. Of interest, species-specific allelic variation in the GroEL homologue of Mycobacterium species (HSP65) has also been utilized for rapid identification and taxonomic classification of mycobacteria in the clinical setting (Pai et al., 1997; Steingrube et al., 1995).

In the current study, we have cloned and sequenced the partial HSP60 genes from 36 staphylococci, representing 28 validly described Staphylococcus species or subspecies. Our results provide direct evidence for the presence of species-specific DNA sequences within the HSP60 genes of staphylococci, and further support the utility of the HSP60 gene as a universal target for the species identification of staphylococci. Furthermore, we demonstrated remarkable agreement in the consensus trees derived from partial HSP60 gene sequences and DNA-DNA reassociation for staphylococci, and that the phylogenetic tree derived from HSP60 DNA sequences correlated better than that from $16 \mathrm{~S}$ rRNA sequences. HSP60 DNA sequences were also more discriminatory than 16S rRNA sequences, since sequence similarity values for 16S rRNA genes among different Staphylococcus species (Table 3) were consistently higher (range 92-99\%; mean 96\%) compared to partial HSP60 gene sequences (range 74-93\%; mean $82 \%$ ) (Table 2). The higher sequence similarity values for 16S rRNA genes compared to HSP60 genes may be due to the likelihood that genes encoding RNA are more evolutionarily ancient and conserved compared to genes encoding proteins. Our findings confirm the earlier observation that $16 \mathrm{~S}$ rRNA sequence analysis lacks resolving power in discriminating between related species within the same genus (Fox et al., 1992). Similar to genomic DNA-DNA reassociation results, the interspecies HSP60 DNA sequence similarity among the staphylococcal isolates varied from 74 to $93 \%$, while subspecies sequence similarity ranged from 91 to $98 \%$. By comparison, the highest sequence similarity of $B$. subtilis and $E$. coli with members within the genus Staphylococcus was only 70 and $59 \%$, respectively (mean 66 and $57 \%$ ). This suggests that HSP60 DNA sequence analysis could be an alternative to DNA-DNA hybridization or $16 \mathrm{~S}$ rRNA sequence analysis for species identification and taxonomic classification within the genus Staphylococcus. Additionally, we identified a 'hot spot' corresponding to nucleotide positions 90-153 in the HSP60 gene sequences of staphylococci, a region which may be critical for the species-specific nature of these DNA sequences among staphylococci. Further research will be required to determine whether HSP60 gene sequences can be similarly utilized for taxonomic classification and phylogenetic analysis of other bacteria besides staphylococci, and whether this 'hot spot' region in the HSP60 gene is also present among bacteria other than staphylococci.

It should not be surprising that HSP60 DNA sequences were more discriminatory than protein sequences in our phylogenetic studies in light of the degeneracy of the genetic code, and the triplet nucleotide coding of specific amino acid residues. Thus, in the pairwise alignments, sequence similarities based on HSP60 proteins were consistently higher than those based on HSP60 DNA for all of the Staphylococcus species studied (Table 2). Analysis of the translated partial HSP60 protein sequences confirmed that all the proteins within the genus Staphylococcus as well as $B$. subtilis and E. coli are highly conserved. Another interesting observation is that the translated partial HSP60 proteins of four Staphylococcus species, $S$. caseolyticus, S. sciuri, S. lentus and S. vitulus, were highly related, and all share a characteristic pattern of amino acid substitutions at positions $39,69,89,151$ and 175 that were different from all the other Staphylococcus species (data not shown). It is also known that these four Staphylococcus species are uniquely different from all other Staphylococcus species in that cytochrome $c$ is present in their electron transport system but not in other Staphylococcus species (Kloos \& Bannerman, 1995). It is unknown whether the common amino acid substitutions observed in the HSP60 proteins of these four species are in any way related to their unique cytochrome oxidase activity.

Finally, it is of some interest to note that based on HSP60 DNA sequences, $S$. caseolyticus was the least similar to the other Staphylococcus species studied, thus lending additional support to the recent decision to remove this organism taxonomically from the genus Staphylococcus, and to describe it as Macrococcus caseolyticus gen. nov., comb. nov. (Kloos et al., 1998).

In summary, our results indicate that DNA sequence analysis of the highly conserved and ubiquitous HSP60 genes may offer advantages over both DNA-DNA hybridization and 16S rRNA sequencing in defining the taxonomy and phylogenetic relationships within the genus Staphylococcus. In addition, our sequence data provide direct evidence for the presence of speciesspecific HSP60 gene sequences, which can be employed as a genotypic method for the species, identification of staphylococci, in particular coagulase-negative staphylococci.

\section{ACKNOWLEDGEMENTS}

We are grateful to Dr W. Kloos of North Carolina State University, Raleigh, NC, USA, for providing some of the strains studied.

\section{REFERENCES}

Altschul, S. F., Madden, T. L., Schaffer, A. A., Zhang, J., Zhang, Z., Miller, W. \& Lipman, D. J. (1997). Gapped BLAST and PSI-BLAST: a new generation of protein database search programs. Nucleic Acids Res 25, 3389-3402. 
Birnbaum, D., Kelly, M. \& Chow, A. W. (1991). Epidemiologic typing systems for coagulase-negative staphylococci. Infect Control Hosp Epidemiol 12, 319-326.

Birnbaum, D., Herwaldt, L., Low, D. E., Noble, M., Pfaller, M., Sherertz, R. \& Chow, A. W. (1994). Efficacy of microbial identification system for epidemiologic typing of coagulasenegative staphylococci. J Clin Microbiol 32, 2113-2119.

Endl, J., Seidl, H. P., Fiedler, F. \& Schleifer, K. H. (1983). Chemical composition and structure of cell wall teichoic acids of staphylococci. Arch Microbiol 135, 215-223.

Euzéby, J. P. (1997). List of bacterial names with standing in nomenclature: a folder available on the Internet. Int $J$ Syst Bacteriol 47, 590-592.

Felsenstein, J. (1995). PHYLIP - Phylogeny Inference Package (version $3.57 \mathrm{c}$ ). Seattle, WA: University of Washington.

Fitch, W. M. (1971). Toward defining the course of evolution: minimum change for a specified tee topology. Syst Zool 20, 406-416.

Fox, G. E., Wisotzkey, J. D. \& Jurtshuk, P., Jr (1992). How close is close: 16S rRNA sequence identity may not be sufficient to guarantee soecies identity. Int $J$ Syst Bacteriol 42, 166-170.

Goh, S. H., Potter, S., Wood, J. O., Hemmingsen, S. M., Reynolds, R. P. \& Chow, A. W. (1996). HSP60 gene sequences as universal targets for microbial species identification: studies with coagulase-negative staphylococci. J Clin Microbiol 34, 818-823.

Goh, S. H., Santucci, Z., Kloos, W. E., Faltyn, M., George, C. G., Driedger, D. \& Hemmingsen, S. M. (1997). Identification of Staphylococcus species and subspecies by the chaperonin 60 gene identification method and reverse checkerboard hybridization. J Clin Microbiol 35, 3116-3121.

Gribaldo, S., Cookson, B., Saunders, N., Marples, R. \& Stanley, J. (1997). Rapid identification by specific PCR of coagulasenegative staphylococcal species important in hospital infection. $J$ Med Microbiol 46, 45-53.

Gupta, R. S. (1995). Evolution of the chaperonin families (Hsp60, Hsp10 and Tcp-1) of proteins and the origin of eukaryotic cells. Mol Microbiol 15, 1-11.

leven, M., Verhoeven, J., Pattyn, S. R. \& Goosens, H. (1995). Rapid and economical method for species identification of clinically significant coagulase-negative staphylococci. $J$ Clin Microbiol 33, 1060-1063.

Jukes, T. H. \& Cantor, C. R. (1969). Evolution of protein molecules. In Mammalian Protein Metabolism, vol. 3, pp. 21-132. Edited by H. N. Munro. New York: Academic Press.

Kloos, W. E. (1997). Taxonomy and systematics of staphylococci indigenous to humans. In The Staphylococci in Human Disease, pp. 113-137. Edited by K. B. Crossley \& G. L. Archer. New York: Churchill Livingstone.

Kloos, W. E. \& Bannerman, T. L. (1995). Staphylococcus and Micrococcus. In Manual of Clinical Microbiology, 6th edn, pp. 282-298. Edited by P. R. Murray, E. J. Baron, M. A. Pfaller, F. C. Tenover \& R. H. Yolken. Washington, DC: American Society for Microbiology.

Kloos, W. E., Ballard, D. N., George, C. G., Webster, J. A., Hubner, R. J., Ludwig, W., Schleifer, K.-H., Fiedler, F. \& Schubert, K. (1998). Delimiting the genus Staphylococcus through description of Macrococcus caseolyticus gen. nov., comb. nov. and Macrococcus equipercicus sp. nov., Macrococcus bovicus sp. nov. and Macrococcus carouselicus sp. nov. Int J Syst Bacteriol 48, 859-877.

Martin de Nicolas, M. M., Vindel, A. \& Saez-Nieto, J. A. (1995).
Epidemiological typing of clinically significant strains of coagulase-negative staphylococci. $J$ Hosp Infect 29, 35-43.

O'Donnell, A. G., Nahaie, M. R., Goodfellow, M., Minnikin, D. E. \& Hajek, V. (1985). Numerical analysis of fatty acid profiles in the identification of staphylococci. J Gen Microbiol 131, 2023-2033.

Olsen, G. J., Woese, C. R. \& Overbreek, R. (1994). The winds of (evolutionary) change: breathing new life into microbiology. $J$ Bacteriol 176, 1-6.

Pai, S., Esen, N., Pan, X. \& Musser, J. M. (1997). Routine rapid mycobacterium species assignment based on species-specific allelic variation in the 65 -kilodalton heat shock protein gene (hsp65). Arch Pathol Lab Med 121, 859-864.

Pillet, J. \& Orta, B. (1981). Species and serotypes in coagulasenegative Staphylococci. In Staphylococci and Staphylocoocal Infections, pp. 147-152. Zentralblatt fur Bakteriologie, Mikrobiologie und Hygiene. I. Abteilung Supplemente, vol. 10. Edited by J. Jeljaszewicz, W. Hryniewicz, L. M. Switalski \& S. Szmigielski. Stuttgart \& New York. Gustav Fischer Verlag.

Rosypal, S., Rosypalova, A. \& Horejs, J. (1966). The classification of micrococci and staphylococci based on their DNA base composition and Adansonian analysis. J Gen Microbiol 44, 281-292.

Schumacher-Perdreau, F., Rotering, H. \& Pulverer, G. (1983). Cell wall analysis and taxonomy of staphylococci. Zentbl Bakteriol Mikrobiol Hyg 1 Abt Orig A 256, 25-36.

Smith, S. (1997). Genetic Data Environment. Harvard Genome Laboratory. Chicago: University of Illinois.

Stackebrandt, E. \& Goebel, B. M. (1994). A place for DNA-DNA reassociation and $16 \mathrm{~S}$ rRNA sequence analysis in the present species definition in bacteriology. Int $J$ Syst Bacteriol 44, 846-849.

Stackebrandt, E., Liesack, W. \& Witt, D. (1992). Ribosomal RNA and rDNA sequence analysis. Gene 115, 255-260.

Steingrube, V. A., Gibson, J. L., Brown, B. A., Zhang, Y., Wilson, R. W., Rajagopalan, M. \& Wallace, R. J., Jr (1995). PCR amplification and restriction endonuclease analysis of a 65-kilodalton heat shock protein gene sequence for taxonomic separation of rapidly growing mycobacteria. J Clin Microbiol 33, 149-153.

Thompson, J. D., Higgins, D. G. \& Gibson, T. J. (1994). CLUSTAL $\mathrm{W}$ : improving the sensitivity of progressive multiple sequence alignment through sequence weighing, position-specific gap penalties and weight matrix choice. Nucleic Acids Res 22, 4673-4680.

Viale, A. M., Arakaki, A. K., Soncini, F. C. \& Ferreyra, R. G. (1994). Evolutionary relationships among eubacterial groups as inferred from GroEL (chaperonin) sequence comparisons. Int $J$ Syst Bacteriol 44, 527-533.

Wayne, L. G., Brenner, D. J., Colwell, R. R. \& 9 other authors (1987). International Committee on Systematic Bacteriology. Report of the ad hoc committee on reconciliation of approaches to bacterial systematics. Int J Syst Bacteriol 37, 463-464.

Yamamoto, S. \& Harayama, S. (1995). PCR amplification and direct sequencing of $g y r B$ genes with universal primers and their application to the detection and taxonomic analysis of $P$ seudomonas putida strains. Appl Environ Microbiol 61, 1104-1109.

Zakrzewska-Czerwinska, J., Gaszewska-Mastalarz, A., Lis, B., Gamian, A. \& Mordarski, M. (1995). Staphylococcus pulvereri $\mathrm{sp.}$ nov., isolated from human and animal specimens. Int $J$ Syst Bacteriol 45, 169-172. 